\title{
Oververtegenwoordiging van jongeren met een migratieachtergrond in de strafrechtketen ${ }^{*}$
}

\author{
Albert Boon, Melissa van Dorp \& Sjouk de Boer
}

\begin{abstract}
Disproportionate minority contact $(D M C)$ is de term die in de Verenigde Staten gebruikt wordt om aan te geven dat een onevenredig groot aantal jongeren uit minderheidsgroepen in contact komt met het strafrechtsysteem. De cijfers over DMC hebben er in de Verenigde Staten voor gezorgd dat het probleem op de politieke agenda is gekomen en er maatregelen zijn genomen om de ongelijkheid te verminderen. In Nederland is een aantal studies gedaan naar de vertegenwoordiging van specifieke etnische minderheidsgroepen in de verdachtenstatistieken, maar tot nu toe ontbreken cijfers over alle groepen in de verschillende fasen van de strafrechtketen. Waarschijnlijk door het gebrek aan een dergelijk overzicht komt DMC (of een equivalent van dit begrip) niet voor in de Nederlandse literatuur en is het geen politiek issue. Daarom is het doel van dit artikel om te onderzoeken of DMC in Nederland bestaat en of het Amerikaanse beleid aanknopingspunten biedt voor de Nederlandse situatie. Om dit te bepalen is de kans (odds ratio's (OR)) berekend voor jongeren met een migratieachtergrond om geregistreerd en aangehouden te worden als verdachte, om een Halt-afdoening te krijgen en om in een jeugdgevangenis terecht te komen. Het blijkt dat de OR voor jongeren met een niet-westerse migratieachtergrond om als verdachte te worden geregistreerd gemiddeld ruim drie keer zo groot is, met een OR van boven de 5 voor sommige etnische groepen. De kans op een Halt-afdoening ligt voor jongeren met een niet-westerse achtergrond juist veel lager. De kans om in een jeugdgevangenis terecht te komen is voor jongeren met een niet-westerse migratieachtergrond ruim zes keer groter dan voor hun autochtone leeftijdgenoten. Voor jongeren van Antilliaanse en Marokkaanse herkomst is die zelfs ruim tien keer groter. Deze resultaten laten zien dat DMC op alle onderzochte momenten in de Nederlandse jeugdstrafrechtketen voorkomt. De oververtegenwoordiging van jongeren met een (met name Marokkaanse en Antilliaanse) migratieachtergrond is dermate groot, dat het belangrijk is om nader onderzoek te doen en programma's te ontwikkelen om DMC te reduceren. Om het probleem goed in kaart te kunnen brengen en maatregelen te evalueren, is het belangrijk om de etnische herkomst van jongeren in alle fasen van de jeugdstrafrechtketen zorgvuldig vast te leggen.
\end{abstract}

\section{Inleiding}

In de Verenigde Staten spreekt men bij significante verschillen in justitiecontacten tussen minderheidsgroepen en de meerderheidsgroep over disproportionate minority contact (DMC). Hoewel deze verschillen zich bij alle leeftijdsgroepen

* Dit onderzoek werd mede mogelijk gemaakt door een bijdrage van de Stichting Vrienden van de Parnassia Groep en de Stichting Steunfonds De Jutters. 
voordoen, zijn ze bij jongeren het grootst. Vandaar dat er in de Verenigde Staten met name aandacht is voor DMC in relatie tot het jeugdstrafrecht (Development Services Group, 2014). Toen duidelijk werd hoe groot de verschillen waren tussen jongeren uit verschillende bevolkingsgroepen, is het op de politieke agenda gekomen en zijn er programma's ontwikkeld om DMC terug te dringen. In Nederland heeft DMC tot dusver nauwelijks aandacht gekregen in beleidstukken of wetenschappelijke publicaties. Het doel van dit artikel is om te onderzoeken of DMC ook in de Nederlandse jeugdstrafrechtketen voorkomt. Allereerst wordt een beschrijving gegeven van DMC in de Verenigde Staten, waarbij de politieke en wetenschappelijke ontwikkelingen rondom DMC worden geschetst alsook strategieën om het te verminderen. Daarna wordt beschreven wat reeds bekend is over de relatie tussen etniciteit en criminaliteit in Nederland. Om een beeld te krijgen van DMC in Nederland zijn vervolgens de beschikbare data van jongeren met en zonder een migratieachtergrond bij verschillende fasen van de jeugdstrafrechtketen geanalyseerd. Met inachtneming van de verschillen in migratieachtergronden van de Amerikaanse en Nederlandse bevolking wordt in de discussie verkend in hoeverre de beschreven verklaringen en oplossingsstrategieën van de Verenigde Staten toegepast zouden kunnen worden in Nederland.

In de Verenigde Staten worden DMC-cijfers over politiecontacten en maatregelen in het jeugdstrafrecht gepubliceerd op de website van het ministerie van Justitie (Puzzanchera \& Hockenberry, 2017). Deze cijfers zijn een feitelijke weergave van de verhoudingen tussen etnische groepen in de statistieken, zonder uitspraken te doen over oorzaken van de verschillen. De cijfers maken het vervolgens wel mogelijk om onderzoek te doen naar de oorzaken van DMC en te onderzoeken of maatregelen die getroffen zijn om DMC te reduceren, effect hebben.

Waar de Amerikaanse overheid zeer open is over cijfers over de relatie tussen etniciteit en criminaliteit, zijn Europese landen veel terughoudender. In Duitsland en Engeland mag slechts onder strikte voorwaarden naar de etnische herkomst van verdachten worden gekeken. Ook België is zeer terughoudend en de Franse overheid kent officieel geen immigranten of minderheden (Van der Leun \& Van der Woude, 2011). Vergeleken met andere Europese landen loopt Nederland voorop wat betreft onderzoek naar de relatie tussen etnische herkomst en criminaliteit (Bovenkerk, 2007; Tonry \& Bijleveld, 2007; Unnever, 2018). De kloof met de Verenigde Staten, waar onderzoek naar DMC door de overheid wordt gestimuleerd, blijft echter groot.

Tussen Nederland en de Verenigde Staten bestaan grote, voornamelijk historisch bepaalde verschillen in het registreren van etnische groepen. In de Verenigde Staten wordt sinds de achttiende eeuw in volkstellingen de categorie 'race or ethnicity' (White American, African American, Indian Native, Asian American, etc.) gebruikt. In Nederland heeft de onwetenschappelijke term 'ras' vooral een negatieve connotatie. Hoewel het woord 'ras' in Nederlandse wetteksten veelvuldig wordt gebruikt, spreekt men in het algemeen liever over etniciteit. Daarnaast is in ons land pas relatief recent aandacht van de overheid voor verschillen tussen etnische groepen gekomen. Niet eerder dan in de tweede helft van de twintigste eeuw, toen bewoners uit de voormalige koloniën en gastarbeiders uit Italië, Spanje, Portugal en later Turkije en Marokko zich hier vestigden, was er aanlei- 
ding om de herkomst te vermelden in de bevolkingsstatistieken. Etnische minderheden worden in ons land geïdentificeerd aan de hand van hun geboorteland of het geboorteland van hun ouders. De grote tegenstelling met de Verenigde Staten is dat mensen met een migratieachtergrond van meer dan een generatie geleden in Nederland niet in de statistieken te traceren zijn, terwijl in de Verenigde Staten ook nakomelingen van bijvoorbeeld de slaafgemaakte Afrikanen uit de zestiende en zeventiende eeuw als 'African Americans' zijn geregistreerd. Voor het onderzoek naar DMC betekent dit dat bij een vergelijking met de Verenigde Staten er bij de Nederlandse bevolkings- en criminaliteitscijfers sprake zal zijn van lagere percentages personen met een migratieachtergrond.

Tot voor kort werd er in Nederland gesproken over eerste en tweede generatie allochtonen. De Wetenschappelijke Raad voor het Regeringsbeleid heeft echter geadviseerd om het woord 'allochtoon' niet meer te gebruiken, maar als ten minste één ouder in het buitenland geboren is te spreken van 'personen met een migratieachtergrond' (Bovens e.a., 2017). In dit artikel is deze terminologie gehanteerd.

\section{DMC in de Verenigde Staten}

Etnische ongelijkheid (racial disparity) in de strafrechtspleging is al lange tijd een politiek thema in de Verenigde Staten. Sinds de eerste Uniform Crime Reports (UCRs) in 1930 is het gebruikelijk om de etnische herkomst van gedetineerden te publiceren. Hierdoor werd de oververtegenwoordiging van bepaalde etnische groepen in de misdaadcijfers duidelijk. Vooral de cijfers over jongeren gaven aanleiding tot zorgen. Daarom amendeerde het Congres in 1988 de wet 'Juvenile Justice and Delinquency Prevention' (JJDP) uit 1974, met als doel beleid te ontwikkelen om disproportionate minority confinement (DMC) bij jongeren tegen te gaan (Hsia e.a., 2004). De aanpak die hieruit volgde, viel uiteen in vijf fasen, namelijk: (1) bepalen in welke mate er sprake was van DMC, (2) de oorzaken van DMC onderzoeken, (3) ontwikkelen van een interventieplan om deze oorzaken aan te pakken, (4) evalueren van de effectiviteit van dit interventieplan en (5) nieuwe ontwikkelingen op dit gebied volgen (Cabaniss e.a., 2007; Pope e.a., 2002). De cijfers uit fase 1 lieten een grote ongelijkheid zien, waardoor DMC in 1992 tot kernonderwerp van beleid werd benoemd. Een deel van de financiering van de staten werd gekoppeld aan de mate waarin zij voldeden aan de eisen van de wet JJDP (Hsia e.a., 2004). In 2002 werd de aanvankelijke focus van de wet JJDP uitgebreid van jongeren in hechtenis naar alle beslismomenten van het jeugdstrafrecht. Vanaf dat moment stond de afkorting DMC voor disproportionate minority contact. Deze term wordt tot op de dag van vandaag in de Verenigde Staten gebruikt om te verwijzen naar het onevenredig grote aantal jongeren uit minderheidsgroepen dat in contact komt met het jeugdstrafrecht.

De oorzaken van DMC zijn complex en het gevolg van een interactie tussen meerdere factoren. Sommige onderzoekers legden daarbij de nadruk op de indirecte effecten van sociaaleconomische status, schoolprestatie en woonomgeving (Kakar, 2006). Zo zou het wonen in een gedesintegreerde wijk sterk gecorreleerd zijn met betrokkenheid van jongeren bij delinquentie. In dergelijke wijken woonden meer eenoudergezinnen en gezinnen met een migratieachtergrond. De scho- 
len waren onder de maat, scholieren spijbelden vaker, bleven vaker zitten en voelden zich minder verbonden met school. Jongeren uit deze wijken waren vaker betrokken bij ernstige delicten dan jongeren in goed geïntegreerde wijken (Junger-Tas e.a., 2012). Andere onderzoekers legden de nadruk op het verschil in kansen tussen jongeren uit verschillende etnische groepen op allerlei maatschappelijke gebieden en benoemden dat kenmerken van het sociale systeem (o.a. juridisch beleid, procedures, regels) bijdragen aan DMC (Huizinga e.a., 2007). Er zou zodoende sprake zijn van een etnische selectiebias in het jeugdstrafrecht die meerdere vormen aan kon nemen (Nellis e.a., 2008), waaronder: etnisch profileren door de politie, de houding van de verhoorder, de officier van justitie of de rechter tegenover verdachten uit minderheidsgroepen en de interactie tussen bewaarders en gedetineerden. Uit een review (Pope e.a., 2002) waarin 34 onderzoeken over DMC geanalyseerd werden, bleek dat de meerderheid (25) van de studies concludeerde dat etniciteit effect had op de manier waarop jongeren binnen het jeugdstrafrecht behandeld werden. Van deze studies rapporteerden er acht dat etniciteit effect had op alle beslismomenten in het contact met het jeugdstrafrecht (zoals arrestatie, verwijzing naar de rechtbank, veroordeling). Zeventien studies rapporteerden gemengde resultaten. Van de resterende negen studies vond één studie geen effect, de andere acht rapporteerden dat het effect van etniciteit niet bepaald kon worden. De conclusie van de review was dat er binnen het Amerikaanse jeugdstrafrecht sprake was van ongelijke behandeling op basis van etnische herkomst in alle stadia van het jeugdstrafrecht (Pope e.a., 2002).

Gezien de complexiteit van de oorzaken van DMC werd in de Verenigde Staten een grote verscheidenheid aan strategieën en programma's ontwikkeld om DMC te verminderen (Hsia e.a., 2004). Het Office of Juvenile Justice and Delinquency Prevention (OJJDP) heeft richtlijnen opgesteld voor het ontwikkelen van een interventieplan (Development Services Group, 2014). Dit interventieplan bestond uit de volgende vijf onderdelen:

1 Ontwerp een brede, maar uitvoerbare benadering.

2 Zorg ervoor dat de strategieën gericht zijn op de belangrijkste beslissingsmomenten.

3 Kies interventies die geïmplementeerd kunnen worden in de gemeenschap.

4 Gebruik evidence-based strategieën en succesvolle ervaringen van de huidige initiatieven.

5 Evalueer de uitkomst van de strategie.

De meest gebruikte strategieën richtten zich op directe zorg (Hsia e.a., 2004) en in enkele staten zijn succesvolle modellen ter vermindering van DMC ontwikkeld (Cabaniss e.a., 2007; Nellis \& Richardson, 2010; Short \& Sharp, 2005).

De maatregelen hebben in de Verenigde Staten volgens de laatste cijfers echter nog niet tot grote landelijke veranderingen geleid (Rovner, 2016). Wel was er, net als in de meeste Europese landen (Van der Laan \& Beerthuizen, 2018), sprake van een sterke afname van het aantal jongeren in jeugdgevangenissen. Deze daling (bijna een halvering tussen 2003 en 2013) was echter niet voor alle etnische groepen even groot. Het bleek dat DMC na deze daling juist groter was geworden. In 2003 was, vergeleken met 'white Americans', de kans (odds ratio) op detentie 
voor Afro-Amerikaanse jongeren 3,7 keer hoger. In 2013 was deze kans gestegen naar 4,3. Voor de Indiaans-Amerikaanse jongeren steeg de kans in deze periode van 2,5 naar 3,7, terwijl voor latino's de kans $(1,6)$ gelijk bleef. In sommige staten lag de verhouding nog schever en was de kans op jeugddetentie voor Afro-Amerikaanse jongeren zelfs tien keer groter (Rovner, 2016).

\section{Aanwijzingen voor DMC in Nederland}

In Nederland worden cijfers over DMC niet systematisch bijgehouden. Anders dan in de Verenigde Staten zijn cijfers over de etnische herkomst van jongeren die in contact komen met politie en justitie niet makkelijk beschikbaar. Het ministerie van Justitie en Veiligheid legt herkomstgegevens niet standaard vast. Daardoor zijn publicaties van verschillende overheidsinstanties slecht vergelijkbaar. Zo werden in het jaaroverzicht 'Criminaliteit en Rechtshandhaving' (Kalidien, 2017) de cijfers van het Centraal Bureau voor de Statistiek (CBS) gebruikt, waardoor de etniciteit wel in de statistieken werd opgenomen, terwijl de Dienst Justitiële Inrichtingen (DJI, 2017) alleen cijfers over geboortelanden gaf, waardoor personen met een migratieachtergrond van de tweede generatie niet te onderscheiden waren. In tegenstelling tot de DJI koppelde het CBS gegevens uit het Herkenningsdienstsysteem van de politie aan de Gemeentelijke Basisadministratie (GBA), waardoor het mogelijk werd om het aandeel van groepen met een migratieachtergrond te berekenen.

Ondanks het ontbreken van eenduidige cijfers is onderzoek beschikbaar waarmee aangetoond kan worden dat er in Nederland sprake is van DMC. Aanvankelijk leek er, op basis van zelfrapportage, onder migrantengroepen minder criminaliteit voor te komen dan onder de autochtone bevolking (Junger-Tas, 1997). Dit beeld is later echter bijgesteld. Zo bleken jongeren uit minderheidsgroepen in Nederland een grotere kans te hebben om met justitie in aanraking te komen (Blokland e.a., 2010; Jennissen, 2009) dan jongeren van Nederlandse herkomst. Ook kwam uit onderzoek naar voren dat adolescenten met een Marokkaanse of Antilliaanse migratieachtergrond oververtegenwoordigd waren in de populatie jeugddelinquenten (Blom \& Van der Laan, 2006; Jennissen, 2009; 2017). Deze bevindingen hebben ook in Nederland geleid tot onderzoek naar verklaringen voor de oververtegenwoordiging. In navolging van het onderzoek in de Verenigde Staten kan hierbij een onderscheid worden gemaakt tussen psychologische, sociale en culturele factoren (Pope e.a., 2002). Psychologische factoren zijn onder andere verklaringen gericht op de relatie tussen het individu en zijn of haar opvoeder(s) en persoonlijkheidstrekken. Zo werden extreem negatieve ervaringen als afwijzing, verwaarlozing en slechte monitoring door ouders geassocieerd met delinquentie (Hoeve e.a., 2009). Sociale factoren betreffen opvoeding, opleiding, vriendschappen, vrijetijdsbesteding en de sociaaleconomische status. In een vroege verkenning (Op den Kamp e.a., 2002) werd een aantal criminele jongeren met een migratieachtergrond geïnterviewd over hun gezinnen en relaties met leeftijdgenoten. Onduidelijk bleef echter in hoeverre hun sociale contacten verschilden van die van niet-criminele leeftijdgenoten. Uit recenter onderzoek kwam naar voren dat de sociale omstandigheden van jongeren met een Marokkaanse achtergrond erg slecht waren. Bepaalde, met geweldsdelicten geassocieerde, varia- 
belen kwamen bij hen vaker voor: zij gingen vaker naar het beroepsonderwijs, beoordeelden de welvaart van hun familie als significant lager en rapporteerden vaker werkloosheid van de ouders dan jongeren met een Nederlandse achtergrond (Lahlah e.a., 2013). Culturele factoren ten slotte, omvatten de culturele achtergrond, integratie, normen en waarden van een persoon. Zo bleken jongeren met een migratieachtergrond een zwaarder strafadvies te krijgen (Komen, 2005). Komen stelde dat dit het gevolg was van hun gebrekkige gewetensontwikkeling en inlevingsvermogen. Dit zou verklaren waarom zij, bij een vergelijkbaar delict en strafblad, hogere straffen kregen dan autochtone jongeren. Ook bleek uit een onderzoek bij adolescenten met een Marokkaanse achtergrond dat veelplegers een sterkere oriëntatie op de Nederlandse maatschappij hadden (Paalman e.a., 2011; Stevens e.a., 2014). Door deze sterke oriëntatie op het gastland zouden er gevoelens van frustratie ontstaan die delinquent gedrag versterken. Daarnaast waren er onderzoeken die wezen op een etnische selectiebias in het jeugdstrafrecht (Eijkman, 2010; Müller, 2016; Van der Leun \& Van der Woude, 2011; Veen e.a., 2011; Weenink, 2008).

Recent is een review verschenen van al het Nederlandse empirisch onderzoek naar de relatie tussen etniciteit en criminaliteit (Unnever, 2018). Unnever concludeerde dat het onderzoek te versnipperd was en dat er vaak tegenstrijdige resultaten werden gevonden. Op de vraag of personen met een migratieachtergrond meer misdaden plegen, kon geen eenduidig antwoord worden gegeven. Dit bleek vooral afhankelijk te zijn van de leeftijd; sommige minderheidsgroepen pleegden tijdens de adolescentie meer delicten, maar de misdaadcijfers voor deze groepen gingen in de volwassenheid weer gelijk op met die van de autochtone bevolking. Een belangrijke conclusie was dat er meer en systematisch onderzoek nodig is (Unnever, 2018). De in het huidige artikel gepubliceerde cijfers over DMC bij jongeren in Nederland kunnen hiertoe hopelijk een bijdrage leveren.

\section{Methode}

De gegevens over de migratieachtergrond van jongeren die met politie en justitie in contact zijn gekomen, zijn opgevraagd bij het ministerie van Justitie en Veiligheid. Een woordvoerder deelde mee dat deze gegevens niet verstrekt konden worden, omdat meestal alleen het geboorteland van de jongere wordt vastgelegd. Aangezien veel tweede generatie migranten hierdoor buiten beeld zouden blijven, achtte het ministerie de gegevens te onbetrouwbaar om te delen met derden. Het ministerie is echter verplicht de gegevens aan te leveren aan het Wetenschappelijk Onderzoek- en Documentatiecentrum (WODC) en het CBS. Het CBS koppelt op zijn beurt de politiegegevens aan de GBA, waarin gegevens over de geboortelanden van de ouders zijn vastgelegd. Hierdoor zijn de gegevens van het CBS over de migratieachtergrond (althans gebaseerd op twee generaties) wel betrouwbaar. Het CBS publiceert echter slechts gegevens over drie momenten in de jeugdstrafrechtketen, namelijk: geregistreerde verdachten, aangehouden verdachten en Halt-afdoeningen. 
Gegevens over de etnische herkomst van pupillen in de Justitiële Jeugd Inrichtingen (JJI's) waren beschikbaar via het WODC (Wartna e.a., 2016). Het WODC baseerde zich hierbij op de administratie van de JJI's. Het WODC rapporteerde, op grond van de door de JJI vastgelegde gegevens over het geboorteland van de ouders, ook de etnische herkomst. Het was echter niet duidelijk van welk percentage van de pupillen het geboorteland van de ouders was vastgelegd. Omdat de data van het WODC niet aan de GBA zijn gekoppeld, is er waarschijnlijk sprake van een onderschatting van het aantal jongeren met een migratieachtergrond. Een beeld van de omvang van deze onderschatting ontstaat door vergelijking met onderzoek waarbij van een steekproef de herkomst van pupillen van de JJI wel zorgvuldig is nagevraagd (Colins e.a., 2013; Vahl e.a., 2014). In deze studies bleek ruim driekwart van de populatie in de JJI een migratieachtergrond te hebben, terwijl dat volgens de opgave van het WODC over dezelfde periode 54,5 procent was. Recentelijk is het WODC gestopt met het vermelden van de etnische herkomst van de pupillen van de JJI's. De laatst gepubliceerde gegevens hierover betroffen de jaren 2008-2012. Daarom is er bij het huidige onderzoek voor gekozen om uit de CBS-databestanden de gegevens over deze periode op te vragen. Alle gegevens betroffen dezelfde leeftijdsgroep (12-17 jaar). Om niet gevoelig te zijn voor jaarlijkse fluctuaties is voor alle berekeningen het jaargemiddelde over deze vijfjaarperiode gebruikt.

De gegevens over de migratieachtergrond van jongeren die geregistreerd of aangehouden zijn, omdat zij verdacht werden van een overtreding of misdrijf (StatLine, 2017c), en de gegevens over jongeren waarbij sprake was van een Haltafdoening (StatLine, 2017b) zijn onttrokken aan StatLine (CBS). Omdat het CBS meer dan 200 herkomstlanden registreert, is gekozen voor de door het CBS gehanteerde driedeling tussen personen met een Nederlandse achtergrond, personen met een westerse migratieachtergrond en personen met een niet-westerse migratieachtergrond. Binnen de niet-westerse groep zijn de gegevens over de etnische groepen die meer dan 1 procent van de totale bevolking in deze leeftijdsgroep uitmaakten (Marokkaanse, Turkse, Surinaamse en Antilliaanse herkomst) apart geanalyseerd.

Voor alle politie- en justitiecontacten zijn, in navolging van Amerikaans onderzoek (Rovner, 2016), de odds ratio's (OR's) berekend voor de minderheidsgroepen, met de autochtone jongeren als referentiegroep. De cijfers zijn afgezet tegen de samenstelling van de bevolking in dezelfde periode en dezelfde leeftijdsgroep (StatLine, 2017a). Ook is het aantal aangehouden jongeren en Halt-afdoeningen afgezet tegen het aantal geregistreerde jongeren. De OR geeft een goed beeld van verschillen tussen groepen, omdat de kans dat er in de ene groep een gebeurtenis optreedt, wordt vergeleken met de kans dat dit gebeurt in de andere groep. Als deze kans in beide groepen even groot is, dan is de OR 1. Alle gepresenteerde OR's vielen binnen het betrouwbaarheidsinterval (CI 95 procent) ${ }^{1}{ }^{1}$ Dit geeft aan dat de gevonden verschillen significant zijn. Hierdoor werd bij alle stappen in de jeugdstrafrechtketen duidelijk hoe de kansen lagen voor jongeren met een migratieach-

1 In grenswaarden van de betrouwbaarheidsintervallen zijn niet in de tabellen opgenomen. De uitgebreide tabellen, inclusief deze waarden zijn op te vragen bij de 1ste auteur (a.boon@lucertis.nl). 
tergrond in vergelijking met hun autochtone leeftijdgenoten. Het gebruik van OR's maakt, ondanks de hierboven geschetste verschillen in registratie, een vergelijking tussen Nederland en de Verenigde Staten mogelijk, omdat werd berekend hoe groot de kans binnen de geregistreerde groepen was op contact met politie en justitie.

\section{Resultaten}

De eerste stap van de strafrechtketen, waar cijfers over beschikbaar waren, betrof jongeren die geregistreerd waren op verdenking van een overtreding of misdrijf. Jongeren met een niet-westerse migratieachtergrond werden beduidend vaker als verdachte geregistreerd. In tabel 1 is te zien dat het percentage van de jonge bevolking dat geregistreerd werd als verdachte bij autochtone jongens 3,6 procent en autochtone meisjes 1,2 procent bedroeg. Deze percentages lagen aanmerkelijk hoger voor alle groepen met een migratieachtergrond. De kans om als verdachte geregistreerd te worden was het hoogst voor jongens met een Marokkaanse achtergrond (vijfenhalf keer groter dan voor autochtone jongens), gevolgd door meisjes van Antilliaanse herkomst (ruim vier keer groter dan voor autochtone meisjes).

Tabel 1 Aantal geregistreerde verdachten in verhouding tot de algemene bevolking 2008-2012 (12-17 jaar)

\begin{tabular}{|c|c|c|c|c|c|c|c|c|}
\hline & \multicolumn{2}{|c|}{ Algemene bevolking } & \multicolumn{6}{|c|}{ Geregistreerde verdachten } \\
\hline & \multirow{2}{*}{$\begin{array}{c}\text { Jongens } \\
\mathbf{N}\end{array}$} & \multirow{2}{*}{$\begin{array}{c}\text { Meisjes } \\
\text { N }\end{array}$} & \multicolumn{3}{|c|}{ Jongens } & \multicolumn{3}{|c|}{ Meisjes } \\
\hline & & & $\mathbf{N}$ & $\%$ & OR & $\mathbf{N}$ & $\%$ & OR \\
\hline Totaal & 609.228 & 581.082 & 30.024 & 4,9 & & 8.898 & 1,5 & \\
\hline Autochtoon & 473.791 & 452.521 & 17.185 & 3,6 & & 5.260 & 1,2 & \\
\hline Westers & 39.792 & 37.722 & 2.522 & 6,3 & $\mathrm{I}, 79$ & 936 & 2,5 & 2,16 \\
\hline Niet-westers & 95.645 & 90.839 & 10.290 & 10,8 & 3,20 & 2.692 & 3,0 & 2,60 \\
\hline Marokko & 19.304 & 18.477 & 3.308 & 17,1 & 5,50 & 708 & 3,8 & 3,39 \\
\hline Antillen $^{\mathrm{a}}$ & 7.338 & 6.869 & 990 & 13,5 & 3,63 & 336 & 4,9 & 4,37 \\
\hline Suriname & $|5.68|$ & 15.153 & 1.494 & 9,5 & 2,80 & 548 & 3,6 & 3,19 \\
\hline Turkije & 22.038 & 20.680 & 1.924 & 8,7 & 2,54 & 370 & I,8 & I,55 \\
\hline
\end{tabular}

a Onder de term Antillen vallen alle eilanden van de voormalige Nederlandse Antillen. OR: odds ratio.

Tabel 2 laat zien dat bij 58,4 procent van de geregistreerde autochtone jongens en bij 49,3 procent van de geregistreerde autochtone meisjes een proces-verbaal was opgemaakt. Deze percentages lagen voor alle minderheidsgroepen hoger dan voor de autochtone groep. Zo blijkt uit tabel 2 dat bij 73,1 procent van de jongens van Antilliaanse herkomst na registratie proces-verbaal werd opgemaakt. Dit leidde voor hen tot een bijna twee keer grotere kans (OR 1,94) om na verdenking te worden aangehouden dan voor autochtone jongens. Alleen voor jongeren met een 
westerse migratieachtergrond was de kans op een proces-verbaal ongeveer gelijk aan die van autochtone jongeren.

Tabel 2 Aantal aangehouden verdachten in verhouding tot het aantal geregistreerde verdachten 2008-2012 (12-17 jaar)

\begin{tabular}{|c|c|c|c|c|c|c|c|c|}
\hline & \multicolumn{2}{|c|}{$\begin{array}{l}\text { Geregistreerde } \\
\text { verdachten }\end{array}$} & \multicolumn{6}{|c|}{ Aangehouden verdachten } \\
\hline & \multirow{2}{*}{$\begin{array}{c}\text { Jongens } \\
\mathbf{N}\end{array}$} & \multirow{2}{*}{$\begin{array}{c}\text { Meisjes } \\
\mathbf{N}\end{array}$} & \multicolumn{3}{|c|}{ Jongens } & \multicolumn{3}{|c|}{ Meisjes } \\
\hline & & & $\mathbf{N}$ & $\%$ & OR & $\mathbf{N}$ & $\%$ & OR \\
\hline Totaal & 30.024 & 8.898 & 18.644 & 62,1 & & 4.604 & $5 I, 7$ & \\
\hline Autochtoon & 17.185 & 5.260 & 10.032 & 58,4 & & 2.594 & 49,3 & \\
\hline Westers & 2.522 & 936 & 1.504 & 59,6 & 1,05 & 480 & 51,3 & $\mathrm{I}, 08$ \\
\hline Niet-westers & 10.290 & 2.692 & 7.028 & 68,3 & $\mathrm{I}, 54$ & 1.518 & 56,4 & 1,33 \\
\hline Marokko & 3.308 & 708 & 2.292 & 69,3 & 1,61 & 392 & 55,4 & 1,28 \\
\hline Antillen & 990 & 336 & 724 & 73,1 & 1,94 & 206 & 61,3 & 1,63 \\
\hline Suriname & 1.494 & 548 & 1.022 & 68,4 & $\mathrm{I}, 54$ & 296 & 54,0 & 1,21 \\
\hline Turkije & 1.924 & 370 & 1.300 & 67,6 & 1,49 & 210 & 56,8 & 1,35 \\
\hline
\end{tabular}

OR: odds ratio.

Dat bij jongeren met een migratieachtergrond verhoudingsgewijs vaker tot aanhouding werd overgegaan, zou verklaard kunnen worden door de aard van de delicten waarvoor zij werden aangehouden. De kansverhoudingen in tabel 2 bleken echter ongeveer gelijk voor alle typen (vermogens-, vernieling en openbareorde-, gewelds- en drugs)misdrijven. Alleen bij verkeersmisdrijven lag de verhouding anders. Bij autochtonen leidde 88,5 procent van de registraties tot een proces-verbaal, terwijl dit bij jongeren met niet-westerse migratieachtergrond 81,5 procent was.

Tabel 3 laat zien wat het effect is van de opeenstapeling van de kansen die in tabel 1 (kans op registratie) en in tabel 2 (kans op proces-verbaal na registratie) gepresenteerd zijn. De tabel geeft per minderheidsgroep weer hoe groot de kans was op een aanhouding (proces-verbaal), gebaseerd op hun aandeel in de bevolking. Uit de tabel blijkt dat de kans op aanhouding voor jongens van Marokkaanse herkomst ruim zes keer groter was dan voor een autochtone jongen (OR 6,23). Ook hier namen meisjes van Antilliaanse herkomst (OR 5,36) een tweede plaats in. 
Tabel 3 Aantal aangehouden verdachten in verhouding tot de bevolking 2008-2012 (12-17 jaar)

\begin{tabular}{|c|c|c|c|c|c|c|c|c|c|c|}
\hline & \multicolumn{4}{|c|}{ Bevolking } & \multicolumn{6}{|c|}{ Aangehouden verdachten } \\
\hline & \multicolumn{2}{|c|}{ Jongens } & \multicolumn{2}{|c|}{ Meisjes } & \multicolumn{3}{|c|}{ Jongens } & \multicolumn{3}{|c|}{ Meisjes } \\
\hline & $\mathbf{N}$ & $\%$ & $\mathbf{N}$ & $\%$ & $\mathbf{N}$ & $\%$ & OR & $\mathbf{N}$ & $\%$ & OR \\
\hline Totaal & 609.228 & 100,0 & 581.082 & 100,0 & 18.644 & 3,1 & & 4.604 & 0,8 & \\
\hline Autochtoon & 473.791 & 77,8 & 452.521 & 77,9 & 10.032 & 2,1 & & 2.594 & 0,6 & \\
\hline Westers & 39.792 & 6,5 & 37.722 & 6,5 & 1.504 & 3,7 & $\mathrm{I}, 82$ & 480 & 1,3 & 2,24 \\
\hline Niet-westers & 95.645 & 15,7 & 90.839 & 15,6 & 7.028 & 7,3 & 3,67 & 1.518 & $\mathrm{I}, 7$ & 2,95 \\
\hline Marokko & 19.304 & 3,2 & 18.477 & 3,2 & 2.292 & 11,9 & 6,23 & 392 & 2,1 & 3,76 \\
\hline Antillen & 7.338 & 1,2 & 6.869 & 1,2 & 724 & 9,9 & 5,06 & 206 & 3,0 & 5,36 \\
\hline Suriname & $|5.68|$ & 2,6 & 15.153 & 2,6 & 1.022 & 6,5 & 3,22 & 296 & 2,0 & 3,45 \\
\hline Turkije & 22.038 & 3,6 & 20.680 & 3,6 & 1.300 & 5,9 & 2,89 & 210 & 1,0 & $\mathrm{I}, 78$ \\
\hline
\end{tabular}

OR: odds ratio.

In veel gevallen wordt bij een eerste politiecontact van jongeren een Halt-afdoening voorgesteld. Hierdoor kan worden voorkomen dat er proces-verbaal wordt opgemaakt. De jongere wordt de keuze tussen justitie en Halt voorgelegd. Het voordeel van Halt is dat de jongere geen strafblad krijgt, omdat de straf buiten justitie om wordt geregeld. De politie, een buitengewoon opsporingsambtenaar (bijv. een leerplichtambtenaar) of het Openbaar Ministerie kan jongeren naar Halt verwijzen. In tabel 4 zijn de kansen op een Halt-afdoening voor de verschillende etnische groepen weergegeven.

Tabel 4 Aantal geregistreerde verdachten in verhouding tot de Halt-jongeren 2008-2012 (12-17 jaar)

\begin{tabular}{|c|c|c|c|c|c|c|c|c|}
\hline & \multicolumn{2}{|c|}{ Geregistreerd } & \multicolumn{6}{|c|}{ Halt } \\
\hline & \multirow{2}{*}{$\begin{array}{c}\text { Jongens } \\
\mathbf{N}\end{array}$} & \multirow{2}{*}{$\begin{array}{c}\text { Meisjes } \\
\mathbf{N}\end{array}$} & \multicolumn{3}{|c|}{ Jongens } & \multicolumn{3}{|c|}{ Meisjes } \\
\hline & & & $\mathbf{N}$ & $\%$ & OR & $\mathbf{N}$ & $\%$ & OR \\
\hline Totaal & 30.024 & 8.898 & 13.562 & 45,2 & & 5.002 & 56,2 & \\
\hline Autochtoon & 17.185 & 5.260 & 9.190 & 53,5 & & 3.070 & 58,4 & \\
\hline Westers & 2.522 & 936 & 974 & 38,6 & 0,55 & 446 & 47,7 & 0,65 \\
\hline Niet-westers & 10.290 & 2.692 & 3.194 & 31,0 & 0,39 & 1.432 & 53,2 & 0,81 \\
\hline Marokko & 3.308 & 708 & 788 & 23,8 & 0,27 & 362 & 51,1 & 0,75 \\
\hline Antillen & 990 & 336 & 292 & 29,5 & 0,36 & 154 & 45,8 & 0,60 \\
\hline Suriname & 1.494 & 548 & 506 & 33,9 & 0,45 & 280 & 51,1 & 0,75 \\
\hline Turkije & 1.924 & 370 & 746 & 38,8 & 0,55 & 241 & 65,1 & 1,33 \\
\hline
\end{tabular}

OR: odds ratio. 
In tabel 4 is te zien dat de kans om een Halt-afdoening te krijgen voor alle minderheidsgroepen (behalve voor meisjes van Turkse herkomst) een stuk kleiner was in vergelijking met de autochtone groep. Een Marokkaanse jongen bleek $(1 / 0,27) 3,7$ keer minder vaak een Halt-afdoening te krijgen dan een autochtone jongen.

Omdat in gegevens van het WODC (Wartna e.a., 2016) over de populatie van de JJI geen onderscheid is gemaakt binnen de etnische groepen tussen jongens en meisjes, zijn in tabel 5 de JJI-gegevens over de hele groep opgenomen. Omdat uit het rapport van het WODC bleek dat de grote meerderheid van de JJI-pupillen (93,7 procent) van het mannelijk geslacht was, zijn de cijfers over de JJI afgezet tegen de mannen in de algemene bevolking en alle verdachten. Een vergelijking met de hele bevolking (mannen en vrouwen) zou iets hogere OR's hebben opgeleverd.

Het percentage jongeren van de gehele bevolking tegen wie proces-verbaal is opgemaakt (en dus als verdachte geregistreerd was) alsook het percentage van de totale bevolking dat in een JJI terechtkwam, was verschillend onder de herkomstgroepen. Van alle autochtone jongens was 2,1 procent als verdachte aangemerkt en werd 0,08 procent geplaatst in een JJI. Voor de minderheidsgroepen lagen deze percentages aanzienlijk hoger. Met betrekking tot een proces-verbaal varieerden de percentages tussen 3,7-11,9 procent en voor het geplaatst zijn in een JJI tussen 0,2-1,0 procent.

De kans voor jongens met een niet-westerse migratieachtergrond om na procesverbaal in een JJI terecht te komen was ruim twee keer groter (OR 2,04) dan voor autochtone leeftijdgenoten. Omdat de kans op een proces-verbaal (tabel 3) al ongeveer drieënhalf keer groter was, stapelden de effecten zich op. De laatste kolommen van tabel 5 laten zien dat een niet-westerse jongen een 6,6 keer grotere kans had om in een JJI terecht te komen ten opzichte van een autochtone leeftijdgenoot. Voor een jongere met een Antilliaanse of Marokkaanse achtergrond was de kans om gedetineerd te worden ruim tien en ruim twaalf keer groter dan voor een autochtone jongere. Uit tabel 5 blijkt dat van alle verdachten (derde kolom) uiteindelijk 10,2 procent in een JJI terechtkwam (zevende kolom). Van autochtone verdachten kwam 7,6 procent in een JJI terecht, terwijl dit percentage voor Antilliaanse (16,9 procent) en Marokkaanse (16,3 procent) verdachten het hoogst was.

Uit alle cijfers bleken grote verschillen tussen jongens en meisjes. Bij het totaal aantal geregistreerde verdachten lag het percentage bij jongens (4,9 procent) bijna drie keer hoger dan bij meisjes (1,5 procent). Dit was ook het geval bij het aantal aangehouden verdachten (jongens 3,1 procent, meisjes 0,8 procent). Bovendien lag bij meisjes het percentage (56,2 procent) waarbij voor een Haltafdoening gekozen werd beduidend hoger dan bij jongens (45,2 procent). Figuur 1 geeft een overzicht van de OR's in de verschillende fase van de jeugdstrafrechtketen voor jongens uit de etnische minderheidsgroepen. 
Tabel 5 Vergelijking herkomstgroepen aangehouden verdachten en populatie pupillen JJI met de algemene bevolking 2008-2012 (mannen 12-17 jaar)

\begin{tabular}{|c|c|c|c|c|c|c|c|c|}
\hline & \multirow{2}{*}{$\begin{array}{c}\text { Bevolking } \\
\mathbf{N}\end{array}$} & \multicolumn{2}{|c|}{ Aangehouden } & \multicolumn{5}{|c|}{ اנJ } \\
\hline & & $\mathbf{N}$ & $\%^{a}$ & $\mathbf{N}$ & $\%{ }^{b}$ & $O^{c}$ & $\%^{d}$ & $O \mathbf{R}^{\mathbf{n}}$ \\
\hline Totaal & 609.228 & 18.644 & 3,1 & 1.905 & 10,2 & & 0,16 & \\
\hline Autochtoon & 473.791 & 10.032 & 2,1 & 758 & 7,6 & & 0,08 & \\
\hline Westers & 39.792 & 1.504 & 3,7 & $|4|$ & 9,4 & 1,27 & 0,18 & 2,22 \\
\hline Niet-westers & 95.645 & 7.028 & 7,3 & 1.006 & 14,3 & 2,04 & 0,54 & 6,63 \\
\hline Marokko & 19.304 & 2.292 & 11,9 & 373 & 16,3 & 2,38 & 0,99 & 12,30 \\
\hline Antillen & 7.338 & 724 & 9,9 & 122 & 16,9 & 2,48 & 0,86 & 10,55 \\
\hline Suriname & $|5.68|$ & 1.022 & 6,5 & $|5|$ & 14,8 & 2,13 & 0,49 & 6,07 \\
\hline Turkije & 22.038 & 1.300 & 5,9 & 135 & 10,4 & I,42 & 0,32 & 3,85 \\
\hline
\end{tabular}

a Percentage aangehouden verdachten van de gehele mannelijke bevolking.

b Percentage gedetineerden van de mannelijke aangehouden verdachten.

c Kans voor mannelijke aangehouden verdachten om in een Jll terecht te komen.

${ }^{d}$ Percentage gedetineerden vergeleken met de gehele mannelijke bevolking.

${ }^{\mathrm{e}}$ Kans voor gehele mannelijke bevolking om in een Jl terecht te komen.

OR: odds ratio; Jl: justitiële jeugdinrichting.

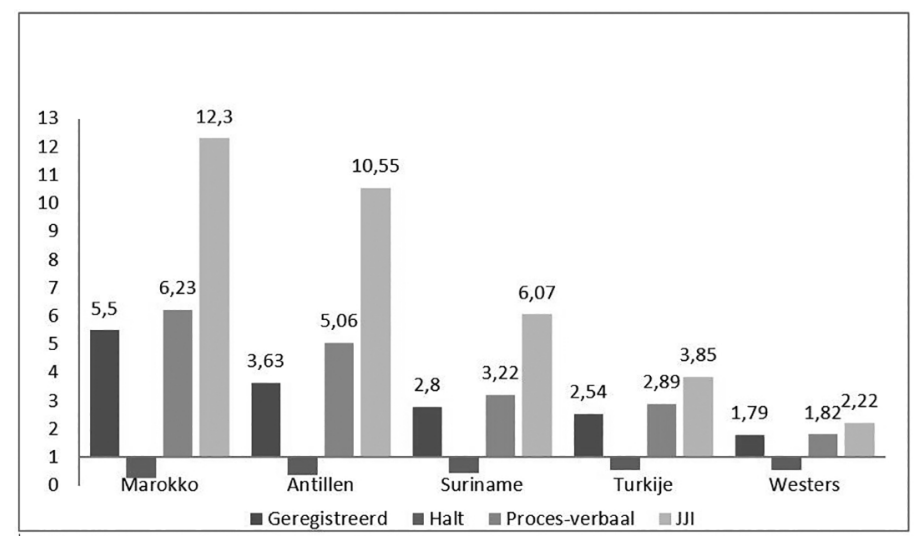

Figuur 1 Odds ratio's jongens uit minderheidsgroepen in de jeugdstrafrechtketen

Tussen 2003 en 2013 daalde het aantal jongeren tegen wie proces-verbaal werd opgemaakt met 41 procent van 24.520 naar 14.560 (StatLine, 2017c). Voor autochtone jongeren daalde dit met 48 procent van 13.410 naar 7.030 , terwijl voor jongeren met een niet-westerse migratieachtergrond de daling (van 8.760 naar 6.140) significant lager was (30 procent). Ook in de periode na 2013 zette de daling van de jeugdcriminaliteit door (Van der Laan \& Beerthuizen, 2018). 


\section{Conclusie}

Jongeren met een migratieachtergrond komen significant vaker voor in de jeugdstrafrechtstatistieken in Nederland. Zij komen vaker in contact met de politie en hun kans om als verdachte geregistreerd te worden, is veel hoger dan voor hun autochtone leeftijdgenoten. Bovendien blijkt de kans om in een JJI terecht te komen voor alle jongeren met een migratieachtergrond vele malen hoger te liggen. Daarmee kan de vraag of er in Nederland sprake is van DMC positief beantwoord worden. Een vergelijking van de omvang van DMC tussen Nederland en de Verenigde Staten wordt bemoeilijkt door verschillen in registratie. In de Verenigde Staten kan de migratiegeschiedenis van eeuwen geleden bepalen of iemand tot een etnische minderheidsgroep behoort, terwijl in Nederland alleen het land van herkomst van de persoon zelf en diens ouders bepalend is. Omdat deze verschillen in registratie echter zowel voor de jongeren in het jeugdstrafrecht als in de algemene bevolking gelden, is een vergelijking op basis van OR's verantwoord. Wanneer de OR's van Nederlandse gedetineerde jongeren vergeleken worden met die van de Verenigde Staten, dan valt op dat DMC in Nederland groter is. In de Verenigde Staten hebben van alle minderheidsgroepen de Afro-Amerikanen de hoogste kans (OR 4,3) om gedetineerd te worden. In Nederland blijken jongeren van Marokkaanse herkomst de grootste kans te hebben (OR 12,3), gevolgd door jongeren met een Antilliaanse achtergrond (OR 10,55). Omdat niet van alle JJIpupillen de etnische herkomst correct geregistreerd is, moet zelfs worden aangenomen dat de kans om in een JJI te belanden voor jongeren met een migratieachtergrond in werkelijkheid nog hoger ligt dan hier berekend is.

Tussen 2003 en 2013 is het aantal jongeren tegen wie proces-verbaal werd opgemaakt sterk gedaald, maar deze daling is minder sterk voor jongeren met een niet-westerse migratieachtergrond. Hierdoor is, net als in de Verenigde Staten, de etnische ongelijkheid (DMC) toegenomen in Nederland. Deze bevinding komt overeen met eerder onderzoek naar jongens met een Marokkaanse achtergrond (Jennissen, 2017).

Alhoewel uit zelfrapportage bleek dat jongeren met een migratieachtergrond zich vaker schuldig maakten aan crimineel gedrag (Junger-Tas e.a., 2012; Steketee e.a., 2016), blijft onduidelijk of de etnische samenstelling van het verdachtenbestand een representatieve afspiegeling is van de werkelijke verhoudingen in de jeugdcriminaliteit. De statistieken kennen een aanzienlijk 'dark number' (nietgeregistreerde criminaliteit) en het is onduidelijk of dit dark number voor alle herkomstgroepen even groot is. De vraag blijft zodoende of oververtegenwoordiging van jongeren uit minderheidsgroepen in de verdachtenstatistieken geheel veroorzaakt wordt doordat zij meer en/of zwaardere delicten plegen of dat het risico om staande gehouden te worden voor hen groter is.

Uit de cijfers blijkt ook dat jongeren met een migratieachtergrond veel minder vaak in aanmerking komen voor een Halt-afdoening. Omdat Halt-afdoeningen aan voorwaarden gebonden zijn op basis van de strafbare feiten en het schadebedrag, kan ook dit het gevolg zijn van de aard en de ernst van hun delicten. 


\section{Verklaringen voor oververtegenwoordiging}

Wanneer de politie uitgaat van uiterlijke kenmerken in plaats van objectief verdacht gedrag, spreekt men over etnisch profileren. Als, bij gelijke criminaliteit binnen verschillende groepen, de ene groep twee keer zo vaak staande wordt gehouden, zal het aantal keer dat een strafbaar feit wordt geconstateerd bij deze groep ook twee keer zo groot zijn. Het is zodoende goed mogelijk dat selectiviteit in het optreden van de politie een factor is die leidt tot een oververtegenwoordiging van personen met een migratieachtergrond in de jeugdstrafrechtketen. Onderzoek wees uit dat etnisch profileren door de Nederlandse politie wordt toegepast (Çankaya, 2012; Eijkman, 2010; Lamers, 2015; Landman \& Kleijer-Kool, 2016) en dat hierdoor de mensenrechten in het geding zijn (Amnesty International, 2013). Jennissen (2017) relativeerde het effect van etnisch profileren echter en stelde dat het geen grote impact heeft op de aantallen verdachten die terechtkomen in de politieregistratie omdat het grootste deel van de verdachten bij de politie in beeld komt dankzij aangiften of tips van burgers. Of gewone burgers zich schuldig maken aan etnisch profileren is nooit onderzocht. Illustratief is echter de documentaire 'Zwart als roet' (Bergman, 2014), waarin een jongeman een fietsslot probeert open te breken. De documentaire laat zien dat burgers bij mannen met een (zichtbare) migratieachtergrond eerder aan diefstal dachten dan bij mannen die deze kenmerken niet hadden. Hoewel het geen wetenschappelijk experiment betrof, maakte de documentaire wel aannemelijk dat ook bij burgers sprake is van een etnische bias bij het signaleren van criminele gedragingen.

Een andere verklaring voor de oververtegenwoordiging van jongeren uit migrantengroepen zou kunnen liggen in de sociaaleconomische omstandigheden. Jongeren uit migrantengroepen groeien vaker op in achterstandswijken, waar zij geconfronteerd worden met nadelige omstandigheden. In een onderzoek waarbij jongens met een Marokkaanse achtergrond werden vergeleken met autochtone leeftijdgenoten met dezelfde sociaaleconomische omstandigheden (Jennissen, 2017), bleek deze factor echter niet alles te verklaren. De OR voor jongens met een Marokkaanse achtergrond om verdacht te worden van een misdrijf lag in dit onderzoek weliswaar lager dan in ons onderzoek, maar bleek nog steeds vier keer zo hoog als voor hun autochtone buurtgenoten. Ook de vergelijking tussen jongeren van Turkse en Marokkaanse herkomst die in soortgelijke sociaaleconomische omstandigheden opgroeien (FORUM, 2008), liet zien dat jongeren van Turkse herkomst minder dan half zo vaak in aanraking kwamen met de politie als jongeren van Marokkaanse herkomst. De etnische diversiteit van de woongemeente kan hierbij een rol spelen omdat bleek dat bij een grotere diversiteit de kans op het plegen van delicten toenam (Jennissen e.a., 2018). Het is daarom aannemelijk dat de sociaaleconomische omstandigheden slechts een deel van de oververtegenwoordiging kunnen verklaren en dat culturele factoren waarschijnlijk ook een rol spelen.

In een recente evaluatiestudie van Halt werd ook geconstateerd dat jongeren met een niet-westerse achtergrond minder vaak door Halt werden bereikt (Buysse e.a., 2017). Als oorzaak noemden de auteurs dat het bekennen van schuld een voorwaarde is voor doorverwijzing naar Halt en dat jongeren met een niet-westerse herkomst daartoe minder geneigd zijn. De hoge cijfers in de jeugdstrafrechtketen 
voor deze jongeren zou zodoende mede verklaard kunnen worden door culturele factoren. De terughoudendheid om schuld te bekennen speelde mogelijk ook een rol bij de opvallende discrepantie tussen zelfrapportage en geregistreerde criminaliteitscijfers bij jongeren van Marokkaanse herkomst. Zij scoorden, in vergelijking met andere groepen, opvallend laag bij de zelfrapportage (Steketee e.a., 2016), terwijl zij over het algemeen het hoogst scoorden in de criminaliteitsstatistieken. Ook bleek dat bij jongeren met een Marokkaanse achtergrond de grootste discrepantie bestond tussen officiële politiegegevens en hun eigen weergave van hun contacten met de politie (Van Batenburg-Eddes e.a., 2012).

Dat er genuanceerd naar de rol die culturele achtergrond speelt, moet worden gekeken, kan worden afgeleid uit een vergelijking tussen minderheidsgroepen met een vergelijkbare achtergrond. Zo zijn de jongeren met een Turkse en Marokkaanse migratieachtergrond deels vergelijkbaar. Beide groepen hebben, als afstammelingen van de gastarbeiders uit de jaren zestig en zeventig, een vergelijkbare geschiedenis. Ook hebben zij over het algemeen een vergelijkbare islamitische culturele achtergrond. Toch zijn er grote verschillen tussen de groepen waar het hun contacten met politie en justitie betreft. De kans op proces-verbaal is voor jongeren met een Marokkaanse achtergrond ongeveer twee keer zo groot als voor hun leeftijdgenoten met een Turkse achtergrond. De kans op jeugddetentie is voor de Marokkaanse groep zelfs ruim drie keer groter dan voor de Turkse groep. Ook tussen jongeren met een Surinaamse en Antilliaanse migratieachtergrond zijn er overeenkomsten. Beide groepen vinden hun herkomst in de voormalige Nederlandse koloniën, waarvan grote groepen rond de dekolonisatie in de tweede helft van de twintigste eeuw naar het voormalige moederland kwamen. Ook hier zijn er grote verschillen in de criminaliteitscijfers. De kans op procesverbaal is voor jongeren met een Antilliaanse achtergrond anderhalf keer zo groot als voor jongeren met een Surinaamse achtergrond en de kans op detentie bijna twee keer zo groot. Onderzoek zou zich zodoende vooral moeten richten op de factoren die de verschillen tussen deze groepen kunnen verklaren.

Tussen het moment van verdenking en de uiteindelijke straftoekenning wordt in de jeugdstrafrechtketen een aantal beslissingen genomen. Helaas ontbreken daarbij vooralsnog de gegevens over de etnische herkomst van de jongeren. Dit maakt het moeilijk om te onderzoeken of, zoals in de Verenigde Staten is aangetoond (Pope e.a., 2002), de etnische herkomst een rol speelt bij deze beslissingen. Bij de zaken waarbij door de rechtbank uitspraak over minderjarigen wordt gedaan, wordt in het overgrote deel een taakstraf opgelegd. Bij slechts een klein deel is sprake van een (deels) onvoorwaardelijke celstraf en komt de jeugdige in een JJI terecht (Wang e.a., 2004). Aangezien het jeugdstrafrecht een sterk pedagogisch karakter heeft, staat bij de berechting van minderjarigen het doel om herhaling te voorkomen voorop. De rechter kan tot verschillende maatregelen besluiten, zoals 'Plaatsing in een Inrichting voor Jeugdigen' (PIJ-maatregel), 'Gedragsmaatregelen' (bijv. trainingen in agressieregulatie) of het betalen van een schadevergoeding. Bekend is dat jongeren met een migratieachtergrond een zwaarder strafadvies kregen (Komen, 2005) en minder vaak in een behandelsetting terechtkwamen (Vreugdenhil e.a., 2004). Helaas ontbreken de statistische gegevens over etnische herkomst van jongeren die de verschillende maatregelen opgelegd krij- 
gen. Om een verklaring te kunnen geven voor de grote verschillen tussen de etnische groepen verdachten die uiteindelijk in een JJI terechtkomen, zouden meer gegevens bekend moeten zijn om de relatie tussen de zwaarte van de delicten, etnische herkomst van de verdachten en de opgelegde straf of maatregelen te onderzoeken.

Onderzoek (Vermeiren, 2003) toonde aan dat een groot deel van de delinquente jongeren een psychiatrische stoornis heeft. Bekend is dat kinderen met onbehandelde psychiatrische problemen op latere leeftijd een grotere kans hebben op schooluitval, middelengebruik en delinquentie (Copeland e.a., 2007; Lochman \& Salekin, 2003; Moffitt e.a., 2002). Mogelijk kan een deel van de oververtegenwoordiging van sommige etnische minderheidsgroepen worden verklaard uit het gegeven dat zij als kind minder professionele hulp krijgen bij psychiatrische problemen. De kans dat kinderen met een migratieachtergrond met psychiatrische problemen de juiste behandeling krijgen, was ongeveer half zo groot als voor hun autochtone leeftijdgenoten. In migrantenwijken lag die kans zelfs nog lager (Boon e.a., 2010a). Omdat psychiatrische problemen minder onderkend en behandeld werden bij kinderen met een migratieachtergrond, was de kans op delinquent gedrag in deze groep dus groter. Bij een deel van deze jongeren komt de psychiatrische stoornis alsnog aan het licht wanneer ze vanwege delinquent gedrag bij een rechter belanden, waardoor hun kans op een behandeling in de forensische jeugdpsychiatrie veel hoger lag (Boon e.a., 2010b). Uit het feit dat bij 70 tot 90 procent van de jeugdige gedetineerden sprake was van minstens één psychiatrische stoornis (Colins e.a., 2010; Vreugdenhil e.a., 2004), bleek echter dat de rechter niet altijd onderkende dat er sprake was van psychiatrische problemen.

\section{Aanbevelingen}

Omdat bleek dat het probleem van de oververtegenwoordiging van minderheidsgroepen in de criminaliteitscijfers in Nederland vooral gold voor jongeren (Unnever, 2018), ligt het voor de hand om, net als in de Verenigde Staten, maatregelen te nemen die betrekking hebben op deze leeftijdsgroep. De eerste stap om DMC te verminderen is het in kaart brengen van het probleem (Hsia e.a., 2004), zodat duidelijk is op welke groepen interventies gericht moeten worden. Met de gegevens die beschikbaar waren, hebben wij met dit artikel een eerste stap gezet om DMC in de Nederlandse situatie in kaart te brengen. Aangezien er nog veel cijfers ontbreken, verdient het aanbeveling om, net als in de Verenigde Staten, bij alle stappen in de jeugdstrafrechtketen duidelijk te maken wat de herkomst van de jongeren is. Dit kan door een koppeling van deze gegevens aan de GBA door het CBS, zoals nu al gebeurt bij geregistreerde verdachten, aangehouden verdachten en Halt-afdoeningen. De nieuwe Uitvoeringswet Algemene verordening gegevensbescherming (AVG) is weliswaar zeer streng wat betreft het vastleggen van gegevens over etnische herkomst, maar maakt een nadrukkelijke uitzondering voor wetenschappelijk onderzoek en statistiek (art. 22 AVG). In combinatie met de gegevens over de aard en zwaarte van de delicten kan zo duidelijk worden of er sprake is van een etnische bias bij de beslissingen die genomen worden.

Als op grond van bovenstaande meer duidelijk wordt over de aard en de omvang van $\mathrm{DMC}$, dient een plan van aanpak te worden opgesteld. Hierbij kunnen de 
richtlijnen voor het ontwikkelen van een interventieplan, opgesteld door de OJJDP (Development Services Group, 2014), een goed begin vormen. Onderzoek naar de culturele, etnische en sociaaleconomische factoren van jeugdcriminaliteit moet tot beleid leiden dat voorkomt dat bepaalde etnische groepen zich vaker schuldig maken aan crimineel gedrag. Tijdens het eerste kabinet-Rutte is het 'doelgroepenbeleid' afgeschaft. De cijfers over jeugdcriminaliteit geven echter voldoende aanleiding om dit besluit te heroverwegen en preventie- en interventieprogramma's te ontwikkelen die gericht zijn op jongeren uit de meest risicovolle etnische minderheidsgroepen.

Omdat duidelijk is dat onbehandelde psychiatrische stoornissen kunnen leiden tot delinquent gedrag, is het aannemelijk dat de etnische ongelijkheid in de jeugdstrafrechtketen kan worden teruggedrongen door een betere onderkenning en behandeling van deze stoornissen bij jongeren met een migratieachtergrond. Daarom moet de toegang tot de jeugd-ggz voor migrantengroepen verbeterd worden, zodat zij tijdig geholpen worden en daarmee de kans kleiner wordt dat zij met justitie in aanraking komen. Daarnaast moeten delinquente jongeren met een migratieachtergrond beter gescreend worden om te bepalen of er sprake is van psychiatrische problematiek.

Halt is een succesvolle aanpak, die ertoe leidt dat veel jongeren een tweede kans krijgen en wordt voorkomen dat een jeugdzonde uitmondt in een criminele carrière (Buysse e.a., 2017). De cijfers laten echter zien dat jongeren met een migratieachtergrond veel minder toegang hebben tot Halt en dat het succes van deze aanpak zich vooral beperkt tot de autochtone jongeren. Daarom zal volop moeten worden ingezet op een werkwijze om ook jongeren (en hun ouders) met een migratieachtergrond met de Halt-aanpak te bereiken.

Het is van groot belang te onderzoeken of er sprake is van een etnische bias in de jeugdstrafrechtketen. Op grond van cijfers over DMC in alle fasen van het jeugdstrafrechtsysteem kan worden getoetst of het grondrecht dat iedereen voor de wet gelijk is' (art. 1 Grondwet) en dat 'iedereen in gelijke gevallen, gelijk behandeld dient te worden' wordt nageleefd. Waar het opsporingsapparaat en de rechtspraak afwijken van dit principe, dient dit te worden gecorrigeerd.

\section{Beperkingen}

De bevindingen zijn gebaseerd op secundaire analyses van CBS- en WODC-gegevens. De keuzes die gemaakt zijn bij het samenstellen van de gebruikte bestanden (bijv. meerdere aanhoudingen van één persoon) kunnen de resultaten beïnvloed hebben. Een andere beperking is dat de gegevens van jongeren in een JJI niet gekoppeld konden worden aan de GBA. Dit heeft tot gevolg dat de kans voor jongens met een niet-westerse migratieachtergrond om in een JJI terecht te komen in werkelijkheid vermoedelijk hoger ligt.

Omdat het vooralsnog niet mogelijk is om de stromen door de jeugdstrafrechtketen te volgen, tonen de gepresenteerde gegevens een momentopname. Zij geven een beeld van het aantal jongeren dat zich in de afgebakende periode op enkele plekken in de strafrechtketen bevond.

Naast gegevens over herkomst, zouden ook andere factoren betrokken moeten worden om een goed beeld te krijgen van de werkelijke omvang van etnische 
ongelijkheid in ons jeugdstrafrecht. Zo zou voor sociaaleconomische status (zie Jennissen, 2017) en opleidingsniveau gecorrigeerd moeten worden. Een combinatie van deze gegevens zou een beter beeld geven, aangezien de criminaliteitsgegevens van herkomstgroepen dan vergeleken kunnen worden met groepen met gelijke opleiding en sociaaleconomische status. Deze gegevens waren echter niet beschikbaar in de databestanden waarop wij ons onderzoek gebaseerd hebben.

\section{Literatuur}

Amnesty International (2013). Proactief politieoptreden vormt een risico voor mensenrechten. Etnisch profileren onderkennen en aanpakken. Amsterdam: Amnesty International Afdeling Nederland.

Batenburg-Eddes, T. van, Butte, D., van de Looij-Jansen, P., Schiethart, W., Raat, H., de Waart, F., \& Jansen, W. (2012). Measuring juvenile delinquency: How do self-reports compare with official police statistics?

European Journal of Criminology, 9, 23-37.

Bergman, S. (2014). Zwart als roet/Our colonial hangover (documentaire). De Familie Film \& TV/VPRO TV.

Blokland, A., Grimbergen, K., Bernasco, W. \& Nieuwbeerta, P. (2010). Criminele carrières van autochtone en allochtone jongeren uit het geboortecohort 1984. Tijdschrift voor Criminologie, 52(2), 122-152.

Blom, M. \& Laan, A. van der (2006). Monitor Jeugd Terecht. Den Haag: Wetenschappelijk Onderzoek- en Documentatiecentrum.

Boon, A., Haan, A. de \& Boer, S. de (2010a). Cliënten Haagse jeugd-ggz geen etnische afspiegeling van de jeugd van de stad; niet door sociaaleconomische status, maar door etnische herkomst. Tijdschrift voor Psychiatrie, 52(9), 652-658.

Boon, A., Haan, A. de \& Boer, S. de (2010b). Verschillen in etnische achtergrond van forensische en reguliere Jeugd-GGZ cliënten. Kind en Adolescent, 31, 16-28.

Bovenkerk, F. (2007). Een taboe op de criminologische verklaringen van misdaad? In: A. Soeteman \& F. van den Born (red.). De ethiek van sociaalwetenschappelijk onderzoek. Amsterdam: KNAW, 11-16.

Bovens, M., Bokhorst, M., Jennissen, R. \& Engbersen, G. (2017). Migratie en classificatie: naar een meervoudig migratie-idioom. Den Haag: Wetenschappelijke Raad voor het Regeringsbeleid.

Buysse, W., Abraham, M., Hofstra, D. \& Dijk, B. van (2017). Werkzaamheid van de Haltafdoening. Den Haag: Wetenschappelijk Onderzoek- en Documentatiecentrum.

Cabaniss, E., Frabutt, J., Kendrick, M. \& Arbuckle, M. (2007). Reducing disproportionate minority contact in the juvenile justice system: promising practices. Aggression and Violent Behavior, 12(4), 393-401.

Çankaya, S. (2012). De controle van marsmannetjes \& ander schorriemorrie: beslissingsproces tijdens proactief politiewerk. Den Haag: Boom Lemma.

Colins, O., Vermeiren, R., Vreugdenhil, C., Van den Brink, W., Doreleijers, T. \& Broekaert, E. (2010). Psychiatric disorders in detained male adolescents: a systematic literature review. Canadian Journal of Psychiatry, 55(4), 255-263.

Colins, O., Boonmann, C., Veenstra, J., Van Domburgh, L., Buffing, F., Doreleijers, T. et al. (2013). Mental health problems and recidivism among detained male adolescents from various ethnic origins. European Child \& Adolescent Psychiatry, 22(8), 481-490. 
Copeland, W., Miller-Johnson, S., Keeler, G., Angold, A. \& Costello, J. (2007). Childhood psychiatric disorders and young adult crime: a prospective, population-based study. American Journal of Psychiatry, 164(11), 1668-1675.

Development Services Group (2014). Disproportionate minority contact. Retrieved from https://www.ojjdp.gov/mpg/litreviews/Disproportionate_Minority_Contact.pdf.

DJI (2017). DJI in getal 2012-2016. Den Haag: Dienst Justitiële Inrichtingen.

Eijkman, Q. (2010). Has the genie been let out of the bottle? Ethnic profiling in the Netherlands. Public Space: The Journal of Law and Social Justice, 5, 1.

FORUM (2008). Factbook. De positie van moslims in Nederland: feiten en cijfers. Utrecht: FORUM, Instituut voor Multiculturele Ontwikkeling.

Hoeve, M., Dubas, J., Eichelsheim, V., Laan, P. van der, Smeenk, W. \& Gerris, J. (2009). The relationship between parenting and delinquency: a meta-analysis. Journal of Abnormal Child Psychology, 37(6), 749-775.

Hsia, H., Bridges, G. \& McHale, R. (2004). Disproportionate minority confinement: 2002 update. Washington, DC: Office of Juvenile Justice and Delinquency Prevention.

Huizinga, D., Thornberry, T., Knight, K., Lovegrove, P., Loeber, R., Hill, K. et al. (2007). Disproportionate minority contact in the juvenile justice system: a study of differential minority arrest/referral to court in three cities. Washington, DC: Office of Juvenile Justice and Delinquency Prevention.

Jennissen, R. (2009). Criminaliteit, leeftijd en etniciteit. Over de afwijkende leeftijdsspecifieke criminaliteitscijfers van in Nederland verblijvende Antillianen en Marokkanen. Den Haag: Boom Juridische uitgevers.

Jennissen, R. (2017). Trends in de overrepresentatie van jongens en jongemannen met een Marokkaanse achtergrond in de verdachtenstatistiek. Justitiële verkenningen, 43(1), 50-70.

Jennissen, R., Engbersen, G., Bokhorst, M. \& Bovens, M. (2018). De nieuwe verscheidenheid: toenemende diversiteit naar herkomst in Nederland. Den Haag: Wetenschappelijke Raad voor het Regeringsbeleid.

Junger-Tas, J. (1997). Ethnic minorities and criminal justice in the Netherlands. Crime and Justice, 21, 257-310.

Junger-Tas, J., Marshall, I., Enzmann, D., Killias, M., Steketee, M. \& Gruszczynska, B. (2012). The many faces of youth crime: contrasting theoretical perspectives on juvenile delinquency across countries and cultures. New York: Springer-Verlag.

Kakar, S. (2006). Understanding the causes of disproportionate minority contact: results of focus group discussions. Journal of Criminal Justice, 34, 369-381.

Kalidien, S. (2017). Criminaliteit en rechtshandhaving 2016: ontwikkelingen en samenhangen. Den Haag: Boom juridisch.

Komen, M. (2005). Straatkwaad en jeugdcriminaliteit. Naar een algemene of een etnisch-specifieke aanpak? Apeldoorn: Het Spinhuis.

Laan, A. van der \& Beerthuizen, M. (2018). Monitor Jeugdcriminaliteit 2017: ontwikkelingen in de geregistreerde jeugdcriminaliteit in de jaren 2000 tot 2017. Den Haag: Wetenschappelijk Onderzoek- en Documentatiecentrum.

Lahlah, E., Knaap, L. van der, Bogaerts, S. \& Lens, K. (2013). Making men out of boys? Ethnic differences in juvenile violent offending and the role of gender role orientations. Journal of Cross-Cultural Psychology, 44(8), 1321-1338.

Lamers, M. (2015). Ethnic profiling. Nationale Politie Eenheid Oost-Brabant.

Landman, W. \& Kleijer-Kool, L. (2016). Boeven vangen: een onderzoek naar proactief politieoptreden. Amersfoort: Twynstra Gudde. 
Leun, J. van der \& Woude, M. van der (2011). Ethnic profiling in the Netherlands? A reflection on expanding preventive powers, ethnic profiling and a changing social and political context. Policing and Society, 21(4), 444-455.

Lochman, J. \& Salekin, R. (2003). Prevention and intervention with aggressive and disruptive children. Next steps in behavioral intervention research. Behavior Therapy 34(4), 413-419.

Moffitt, T., Caspi, A., Harrington, H. \& Milne, B. (2002). Males on the life-course persistent and adolescence-limited antisocial pathways: follow-up at age 16. Development and Psychopathology, 14(1), 179-206.

Müller, T. (2016). We do not hang around. It is forbidden. Erasmus Law Review, 9(1), 30-38.

Nellis, A. \& Richardson, B. (2010). Getting beyond failure: promising approaches for reducing DMC. Youth Violence and Juvenile Justice, 8(3), 266-276.

Nellis, A., Greene, J. \& Mauer, M. (2008). Reducing racial disparity in the criminal justice system: a manual for practitioners and policymakers. Washington, DC: Sentencing Project.

Op den Kamp, H., Halfhide, C. \& Driessen, F. (2002). Het ging gewoon vanzelf: de vroege loopbaan van criminele allochtone jongens. Utrecht: Bureau Driessen.

Paalman, C., Van Domburgh, L., Stevens, G. \& Doreleijers, T. (2011). Individual, family and offence characteristics of high risk childhood offenders: comparing nonoffending, one-time offending and re-offending Dutch-Moroccan migrant children in the Netherlands. Child and Adolescent Psychiatry and Mental Health, 5(33). https://www.ncbi.nlm. nih.gov/pmc/articles/PMC3219550/pdf/1753-2000-5-33.pdf

Pope, C., Lovell, R. \& Hsia, H. (2002). Disproportionate minority confinement: a review of the research literature from 1989 through 2001. Washington, DC: Office of Juvenile Justice and Delinquency Prevention.

Puzzanchera, C. \& Hockenberry, S. (2017). National disproportionate minority contact databook. Retrieved from www.ojjdp.gov/ojstatbb/dmcdb/.

Rovner, J. (2016). Racial disparities in youth commitments and arrests. Washington, DC: Sentencing Project.

Short, J. \& Sharp, C. (2005). Disproportionate minority contact in the juvenile justice system. Washington, DC: Child Welfare League of America.

StatLine (2017a). Bevolking; generatie, geslacht, leeftijd en herkomstgroepering. Retrieved from http://statline.cbs.nl/Statweb/publication/?VW=T\&DM=SLNL\&PA=37325\&D1= 0\&D2=1\&D3=13-18\&D4=0\&D5=a\&D6=18-20\&HD=170216-1527\&HDR=G5,G2\& $\mathrm{STB}=\mathrm{G} 1, \mathrm{G} 3, \mathrm{G} 4, \mathrm{~T}$.

StatLine (2017b). Halt-jongeren; delictgroep, geslacht, leeftijd en herkomstgroepering. Retrieved from https://opendata.cbs.nl/\#/CBS/nl/dataset/71930ned/table?graphtype= Table\&ts $=1507466748609$.

StatLine (2017c). Verdachten; delictgroep, geslacht, leeftijd en herkomstgroepering. Retrieved from http://statline.cbs.nl/Statweb/publication/?DM=SLNL\&PA=81947NED\&D1= 0,27-54\&D2=0-2\&D3=1\&D4=0-1,3-8\&D5=15\&HDR=G4,G1,G2,G3\&STB=T\&VW=T .

Steketee, M., Gaag, M. van der \& Wolthuis, A. (2016). Jeugdcriminaliteit onder migranten: internationale vergelijking zelfrapportage en beleid migranten. Utrecht: Kennisplatform Integratie en Samenleving.

Stevens, G., Veen, V. \& Vollebergh, W. (2014). Psychological acculturation and juvenile delinquency: comparing Moroccan immigrant families from a general and pretrial detention population. Cultural Diversity and Ethnic Minority Psychology, 20(2), 254-265.

Tonry, M. \& Bijleveld, C. (2007). Crime and justice in the Netherlands. In: Crime and Justice. An Annual Review. Chicago: The University of Chicago Press, 1-30. 
Unnever, J. (2018). Ethnicity and crime in the Netherlands. International Criminal Justice Review,http://journals.sagepub.com/doi/abs/10.1177/1057567717752218? journalCode $=$ icja

Vahl, P., Colins, O., Lodewijks, H., Markus, M., Doreleijers, T. \& Vermeiren, R. (2014). Psychopathic-like traits in detained adolescents: clinical usefulness of self-report. European Child \& Adolescent Psychiatry, 23(8), 691-699.

Veen, V., Stevens, G., Doreleijers, T. \& Vollebergh, W. (2011). Moroccan adolescent suspect offenders in the Netherlands: ethnic differences in offender profiles. Psychology, Crime \& Law, 17(6), 545-561.

Vermeiren, R. (2003). Psychopathology and delinquency in adolescents: a descriptive and developmental perspective. Clinical Psychology Review, 23(2), 277-318.

Vreugdenhil, C., Doreleijers, T., Vermeiren, R., Wouters, L. \& Van den Brink, W. (2004). Psychiatric disorders in a representative sample of incarcerated boys in the Netherlands. Journal of American Academy of Child and Adolescent Psychiatry, 43(1), 97-104.

Wang, C., Aten, H., Laan van der, A., Brouwers, M., Heide van der, W., BSJ, W., S, B., 2004. Vervolging en berechting, in: Eggen, A., Heide van der, W. (Eds.), Criminaliteit en rechtshandhaving. Boom Juridische Uitgevers, Meppel.

Wartna, B., Tollenaar, N., Verweij, S., Alberda, D. \& Essers, A. (2016). Recidivebericht 2015. Den Haag: Wetenschappelijk Onderzoek- en Documentatiecentrum.

Weenink, D. (2008). Explaining ethnic inequality in the juvenile justice system. An analysis of the outcomes of Dutch prosecutorial decision making. The British Journal of Criminology, 49(2), 220-242. 